Editorial

\title{
Introduction to the Special Issue of Religions-“Domestic Devotions in Medieval and Early Modern Europe"
}

\author{
Salvador Ryan \\ Faculty of Theology, Pontifical University, St Patrick's College, Maynooth, County Kildare, W23 F2H6, Ireland; \\ Salvador.Ryan@spcm.ie
}

Received: 22 March 2020; Accepted: 24 March 2020; Published: 27 March 2020

This Special Issue of Religions focuses on lived religion and devotional practices as found in the domestic settings of late medieval and early modern Europe. More particularly, it investigates to what degree the experience of personal or familial religious practice in the domestic realm and the more public expression of faith in liturgical or communal settings intersected.

When I first chose this theme, my aim was to build on the significant research that has been undertaken in recent years on domestic devotion in the early modern period, most notably the volumes produced by the European Research Council funded interdisciplinary project Domestic Devotions: The Place of Piety in the Italian Renaissance Home (see, for example Brundin et al. 2018; Corry et al. 2017; Corry et al. 2018; and Faini and Meneghin 2018), but also in other studies such as Martin and Ryrie (2012). More broadly, in 2012-2013, the Ecclesiastical History Society chose for its 50th volume of Studies in Church History the theme Religion and the Household, which contains, among others, at least twelve contributions on the early modern period (Doran et al. 2014).

The specific topic of medieval domestic devotion has been slower to generate significant treatments such as those mentioned above, although there have been fine edited collections such as Spicer and Hamilton (2005), which contain a number of medieval essays, and helpful article contributions by Kolpacoff Deane (2013) and others. This collection aims to respond, in part, to the final section of that article, which sets out some directions for future research. Therefore, in its call for contributions, it especially welcomed contributors who wished to consider the relationship between domestic religious practice across medieval Christianity, Judaism and Islam, or to focus in particular on any one of the three faiths. Elisheva Baumgarten's Practicing Piety in Medieval Ashkenaz (Baumgarten 2014) and Megan H. Reid's Law and Piety in Medieval Islam (Reid 2013) serve as excellent exemplars of this kind of study. While welcoming contributions on early modern domestic devotion, it was my hope that a number of the essays gathered in this collection would shed much-needed light on this topic within the broad field of medieval studies. One of my other hopes for this collection was that it would contribute towards a broadening of the geographical range of enquiry: thus, while welcoming contributors writing on Western Europe, articles which examined aspects of domestic devotion in Central and Eastern Europe were especially encouraged. ${ }^{1}$

The response to the call for contributions was very heartening, with a final number of twenty articles published. I am very happy with the geographical spread of contributions, and particularly pleased to see a fine representation of articles from Slavic language regions, whose complementary

1 On this point, I am looking forward to the publication of important forthcoming studies such as that of Suzanna Ivanič whose monograph, The Materiality of Belief: the Spiritual World of Early Modern Prague, which will be published by Oxford University Press. Ivanič has already contributed important essays such as "Amulets and the Material Interface of Beliefs in Seventeenth-Century Prague Burgher Homes" in Domestic Devotions in the Early Modern World (Faini and Meneghin 2018). 
scholarship in this area is much needed in English language publications. I am also delighted to publish two essays on aspects of domestic devotion within Islam during the Ottoman period, and also an essay on domestic practice within medieval Judaism.

The Essays

Albert Kohn uses Hebrew texts from thirteenth-century Southern Germany, primarily Sefer Hasidim, to further analyse the role of beds in shaping medieval domestic devotion and to show how Jewish notions about the social, moral, and sexual significance of the bed also reflect those identified in late medieval Christian culture. There were certain practical considerations to be observed when reciting the shema, for instance, if sharing a bed with another. Also, the mixing of the sacred (a holy text, for example) with the profane bed could only occur if the bed had been newly laundered, to ensure that its sheets had not become polluted by bodily fluids.

Acknowledging that there is very little documentary and/or physical evidence of sensorial engagements with religious artefacts, such as kissing, licking, or stroking, in medieval Norway, Ragnhild M. Bø turns her attention to two church inventories for the parish churches in Hålandsdalen (1306) and Ylmheim (1321/1323). These offer a glimpse of what may have been a semi-domestic devotional practice related to sculpture, namely the embellishing of wooden sculptures in parish churches with silver bracelets and silver brooches. Her aim is to use a few preserved objects and archaeological finds as well as medieval sermons, homiletic texts and events recorded in Old Norse sagas, to tease out the significance of the silver items mentioned in the two inventories by exploring the interfaces between devotional acts, decorative needs, and possibly gendered experiences, as well as object itineraries between the domestic and the religious space.

Juliana Dresvina's article seeks to trace the visual sources of the English mystic Julian of Norwich's (1343 and 1416) Revelations or Showings, and suggests that many of them come from familiar everyday devotional objects such as Psalters, Books of Hours, or rosary beads. It approaches Julian's text from the perspective of neuromedievalism, combining more familiar textual analysis with some recent findings in clinical psychology and neuroscience.

Matko Matija Marušić explores domestic devotional practices in Ragusa (modern-day Dubrovnik) from the late thirteenth through the fourteenth and fifteenth centuries. Considering that important advancements in the understanding of domestic devotions in major Mediterranean cities have recently been made-particularly in Venice-the scrutiny of Ragusan sources enables further reflections on the same phenomena in minor Adriatic centres. Given the paucity of preserved objects, and the fact that no late medieval domestic space of that time has survived in Dubrovnik, he turns to archival sources to answer questions pertaining to the arrangements and uses of spaces of domestic worship. Three aspects are analysed in his essay: privately owned chapels-adjoined to the dwellings of urban nobility - prayer areas and holy images inside the houses, and relics in the possession of individuals.

Marta Crispí examines domestic devotion in Catalonia in the thirteenth, fourteenth and fifteenth centuries, based on the information provided by numerous post-mortem inventories and texts written by coetaneous spiritual authors such as Ramon Llull, Francesc Eiximenis and Saint Vincent Ferrer. Among the objects recorded in the inventories, pieces of furniture and devotional objects laypeople and clergymen used in their pious practices as "material" aid for personal prayer stand out. They were in keeping with the strong visual culture that pervaded the later Middle Ages. There were retables, oratories and images of religious themes. However, the inventories also listed lesser known but equally recurring objects such as paternosters and Agni Dei. Painted cloths depicting religious scenes that decorated the homes of numerous wealthy Catalan-Aragonese families at that time were also present. Spiritual books such as books of hours and psalters, biblical texts, Legenda Aurea, etc., were mentioned as well. They were part of the incipient libraries of the laity in the Late Middle Ages.

Karen Ralph considers the major cycles of illumination in two Books of Hours belonging to Thomas Butler, seventh Earl of Ormond (c. 1424-1515). The article concludes that the iconography of the two manuscripts reflects the personal and familial piety of the patron and was designed to act as a tool in the practice of devotion. A prominent figure in English and French public life with an Irish 
heritage, the products of his patronage were influenced by the various facets of his world; marked, as they are, by English prayers, French designs, Irish saints, borrowed folia, and some individual artistic flair. Thomas Butler's Books of Hours were performative objects, family records, "archives of prayer" and material aids to devotion.

Anna Dlabačová studies the role of the earliest books printed in the Dutch vernacular in the religious practice of lay individuals and the devout home. Many of the texts disseminated in these early printed books have received little attention and scholars have tended to view them within the sphere of the Devotia Moderna, even though often there is no direct link to this religious reform movement. This article attempts to show that the first books printed in Dutch offer an interesting lens through which to study domestic devotion in the Low Countries in the last decades of the fifteenth century. It argues that these books bridged the gap between catechetical instruction and the private home, literally bringing home many of the ideals and instructions that the clergy would have offered in church and thus increasingly 'textualizing' the lives of the late medieval laity.

Taking late medieval Florence as her focus of study, Catherine Lawless discusses domestic devotions by framing them in terms of devotions carried out in the home, defined by its opposition to ecclesiastical, consecrated space. It examines how women, considered the laity par excellence through their inability to ever attain sacerdotal authority, were advised spiritually by mendicant friars on how to lead a Christian life according to their status as wives, widows or virgins. It looks at the devotional literature that was widespread in mercantile homes and the devotional images designed to move the soul. This discussion attempts to show the tensions between ecclesiastical and domestic spaces-between the clergy and the laity, and between the corporeal and spiritual worlds of late medieval devotion. It argues that, despite clerical unease with the female and domestic space, the importance accorded to female piety by the mendicant orders at the close of the Middle Ages was such that women were entrusted with key educational roles in the family, even leading to the astonishing affirmation of them as 'preachers' within the borders of their households.

Sarah Blick uses material culture to examine late medieval domestic devotional practices. These survivals ranged from very fine examples to their low-quality, mass-produced counterparts, demonstrating that similar devotional interests and practices spanned all social strata. They included pilgrim badges; amulets inscribed with sacred names or prayers; three-dimensional figures; tiny folding pewter triptychs or diptychs; lockets, chains and cylinders; and even bells, whistles and rattles which could acquire a quasi-devotional function.

Margarita Voulgaropoulou's contribution, on icons in the late medieval and early modern Adriatic, examines how icon veneration became deeply rooted in the Catholic societies of the broad Adriatic region, and particularly in domestic households. However, some important crossovers can be identified, especially in instances where these household icons were donated to churches as votive offerings and therefore entered another devotional space as a result, becoming focal points of more public devotion.

Kaja Merete Haug Hagen examines a late medieval paper amulet containing prayers to St Dorothy and the Holy Cross which was found under the floorboards in a demolished part of a medieval wooden stave church in Torpo, Norway. From the perspective of materiality and sensory-based religious practices, this article explores the connection between the textual amulet found in Torpo and its relation to the now-lost large wooden cross in Torpo church, and to crosses believed to be wonderworking or miraculous in its proximity. The amulet may have been placed in the church, but this was not its original home. Here, once again, we have a connection between what may have been a domestically possessed religious item and its final destination, which was a formal ecclesiastical space.

Zuzanna Sarnecka turns her attention to the function of small-scale maiolica sanctuaries and chapels created in Italy in the sixteenth century. The so-called eremi encouraged a multisensory engagement of the faithful with complex structures that included receptacles for holy water, openings for the burning of incense, and moveable parts. They depicted a saint contemplating a crucifix or a 
book in a landscape and, as such, they provided a model for everyday pious life. The reduced scale made the objects portable and stimulated a more immediate pious experience.

Focusing on the response to the Vatican Pietà and perversely using as a point of departure a 1549 remark on Michelangelo as an "inventor of filth", Grażyna Jurkowlaniec aims to present Michelangelo as an involuntary inventor of devotional images. The article explores hitherto unconsidered aspects of the reception of the Vatican Pietà from the mid-sixteenth into the early seventeenth century. The material includes mediocre anonymous woodcuts, and elaborate engravings and etchings by renowned masters: Giulio Bonasone, Cornelis Cort, Jacques Callot and Lucas Kilian. A complex chain of relationships is traced among various works, some referring directly to the Vatican Pietà, some indirectly; none were designed or perceived as reproductions of it, but were conceived as illustrations of the Syriac translation of the New Testament, of Latin and German editions of Peter Canisius's Little catechism, of the frontispiece of the Règlement et établissement de la Compagnie des Pénitents blancs de la Ville de Nancy — but, above all, they were widespread as single-leaf popular devotional images.

Milena Ulčar, focusing on the early modern Bay of Kotor, in modern-day Montenegro, explores how the use of illegally acquired body parts (through grave exhumation, for example) for healing in the domestic sphere mirrored the function and use of official saints' relics in more controlled ecclesiastical settings. By borrowing and adopting iconographic and ritual elements from each other, the church authorities and common people participated in a shared devotional world in which the fragmented body and its creative (mis)use possessed healing powers.

Examining Arabic texts of the Ottoman period, Torsten Wollina shows how appropriating the margins and blank spaces for notes of a sacred or revered text with one's own domestic or family life, any 'academic' or 'religious' manuscript could be turned into an object of domestic devotion. Placing notes-and thus the names of dear ones-in close proximity to revered texts and the handwriting of esteemed individuals was, in itself, an aim of a devotional practice.

Shrine visitation (ziyāra) and devotion to Muhammad (such as expressed in taṣliya, the uttering of invocations upon the Prophet), both expressed through a range of ritualized practices and material objects, were at the heart of everyday Islam for the vast majority of early modern Ottoman Muslims across the empire. While both bodies of practice had communal and domestic aspects, Jonathan Parkes Allen focuses on the important intersections of the domestic with both shrine-visitation and Muhammad-centered devotion as visible in the early modern Ottoman lands, with a primary emphasis on the eighteenth century. While saints' shrines were communal and "public" in nature, a range of attitudes and practices associated with them, recoverable through surviving physical evidence, travel literature, and hagiography, reveal their construction as domestic spaces of a different sort, appearing to pious visitors as the "home" of the entombed saint through such routes as wall-writing, gender-mixing, and dream encounters. Devotion to Muhammad, on the other hand, while having many communal manifestations, was also deeply rooted in the domestic space of the household, in both prescription and practice. Through an examination of commentary literature, hagiography, imagery and objects of devotion, particularly in the context of the famed manual of devotion Dala' $i l$ al-khayrāt, Allen demonstrates the transformative effect of such devotion upon domestic space and the ways in which domestic contexts were linked to the wider early modern world, Ottoman, and beyond.

Jantina Ellens demonstrates the malleability of some textual aids to domestic devotion. She focuses her attention on Devotions in the Ancient Way of Offices, a Catholic primer first published in 1668, which highlighted the continual usefulness of medieval devotional practice, but which was subsequently adapted for use by late seventeenth and early eighteenth century English Protestants. This article demonstrates how attempts to reclaim early church faith practices through the recuperation of medieval devotional methods was a significant feature of seventeenth century confessional debates.

Terese Zachrisson, in an article on seventeenth century Sweden, notes how it is a common saying in parts of rural Sweden, when discussing someone lacking in piety, that they went to neither church nor cross. This saying reflects the practice of placing shrines in the fields, along the roads and in the woods as a communal, semi-domestic site that complemented official church space. In the remote woodland 
areas of Sweden, the distance between parish churches could be considerable, and many parishioners were not able to attend church on a regular, weekly basis. Here, then, parishioners could kneel and make their prayers when unable to attend church service. These sites could also be used as points of contact when communicating with the divine about domestic issues. For instance, votive offerings were often left at the shrines by those hoping for deliverance from disease and difficult childbirths. Zachrisson's article positions itself at the interface between domestic and ecclesial religious practice.

Aleksandra Sulikowska-Belczowska examines the role of domestic icons in the seventeenth and eighteenth centuries as a material foundation of the identity of the Old Believers movement in Russia, and how icons became a source of heated controversy between Old Believers and the Patriarch Nikon who forbade icons after the 'Western style' to be painted or to be held in people's houses. Likewise, the Old Believers' prayer houses were always full of icons, but most of them were domestic icons, i.e., icons of relatively small size and of specific iconography, with a definite predominance of images of the Mother of God, Christ, and angels or saints, especially St. Nicholas the Miracle Worker. Here, again, we see the crossover between domestic and ecclesial space.

By way of a precise case study, i.e., Palazzo Scordia in Palermo (Sicily) in the late seventeenth and early eighteenth century, Valeria Viola examines familial devotion and its relationship with parts of the house other than the chapel. It aims to problematize the issue of the devotional/non-devotional use of paintings inside the household. Of particular note, especially when considered in relation to Albert Kohn's article on the medieval Jewish bed, is Giulio Mancini's Alcune considerazioni appartenenti alla pittura come di diletto di un gentiluomo (1617-1621), which prescribes the bedroom as among the most suitable locations for "le cose di devotione" ("items for devotion"). The article illustrates that the path approaching the chapel from the rest of the house was characterized by the crossing of numerous consecutive thresholds marked by an increase in religious images hanging on the walls. Viola concludes by cautioning that, after years in which the early modern house has been assessed as a secular place alien to devotional practices, the risk is now to go towards the opposite extreme; that is, the univocal interpretation of the house as a "devotional place", thus neglecting the complexity and the instability of meanings that spaces, images, and objects sustained in the domestic environment.

Some Concluding Remarks

In conclusion, it is my hope that this collection of articles has managed to achieve what it set out to do, at least for the most part. Just over half of the contributions deal wholly, or in large part, with the later Middle Ages (fulfilling the desideratum of increasing the number of studies of medieval domestic devotion); there is a fairly wide geographical range (which includes several welcome contributions from Eastern Europe); both Judaism and Islam are represented (although I would have liked to have seen some more contributions regarding medieval Judaism and Islam). However, if the collection as a whole inspires others to build further studies on the research gathered here, it will have made an important contribution.

I am enormously grateful to all the scholars who responded to the initial call for contributions and I owe an immense debt of gratitude for the timeliness of their contributions, and also the professionalism and generosity of the numerous anonymous readers of these articles.

Warm thanks are also owed to the dedicated team in the Religions Editorial Office whose courtesy and efficiency have been a joy throughout this process.

As I write this introduction, the global community is in the midst of the COVID-19 pandemic and most people are currently working from their homes and practicing "social distancing". As a result of this crisis, places of worship across the world have had to close their doors and, to prevent further infection, faith communities can no longer gather for communal worship in person. It seems appropriate to conclude with the thought that scholars for whom the communal expression of faith is an integral part of their personal lives now have reason to consider the term "Domestic Devotion" with more than an academic interest.

Conflicts of Interest: The author declares no conflict of interest. 


\section{References}

Baumgarten, Elisheva. 2014. Practicing Piety in Medieval Ashkenaz. Philadephia: University of Pennsylvania Press. Brundin, Abigail, Deborah Howard, and Mary Laven. 2018. The Sacred Home in Renaissance Italy. Oxford: Oxford University Press.

Corry, Maya, Marco Faini, and Alessia Meneghin, eds. 2018. Domestic Devotions in Early Modern Italy. Leiden: Brill. Corry, Maya, Deborah Howard, and Mary Laven, eds. 2017. Madonnas E Miracles: the Holy Home in Renaissance Italy. London: Philip Wilson Press.

Doran, John, Charlotte Methuen, and Alexandra Walsham, eds. 2014. Studies in Church History 50. Religion and the Household. Woodbridge: Boydell.

Faini, Marco, and Alessia Meneghin, eds. 2018. Domestic Devotions in the Early Modern World. Leiden: Brill. Kolpacoff Deane, Jennifer. 2013. Medieval Domestic Devotion. History Compass 11: 65-76. [CrossRef]

Martin, Jessica, and Alec Ryrie, eds. 2012. Private and Domestic Devotion in Early Modern Britain. Farnham: Ashgate. Reid, Megan H. 2013. Law and Piety in Medieval Islam. Cambridge: Cambridge University Press.

Spicer, Andrew, and Sarah Hamilton, eds. 2005. Defining the Holy: Sacred Space in Medieval and Early Modern Europe. Aldershot: Ashgate.

(C) 2020 by the author. Licensee MDPI, Basel, Switzerland. This article is an open access article distributed under the terms and conditions of the Creative Commons Attribution (CC BY) license (http://creativecommons.org/licenses/by/4.0/). 